\title{
New records of two species of parasitic isopods (Isopoda: Cymothoida: Bopyridae: Athelginae) associated with hermit crabs from the south Atlantic
}

\author{
Felipe Bezerra Ribeiro'; Ivanklin Soares Campos-Filho² \& Luís Ernesto Arruda Bezerra ${ }^{3}$ \\ 1 Universidade Federal do Rio Grande do Sul (UFRGS), Instituto de Biociências (IBIO), Departamento de Zoologia, \\ Programa de Pós-Graduação em Biologia Animal (PPGBAN). Porto Alegre, RS, Brasil. \\ ORCID: http://orcid.org/0000-0002-8623-1576. E-mail: fbribeiro.bio@gmail.com (corresponding author) \\ 2 Universidade Federal de Campina Grande (UFCG), Programa de Pós-Graduação em Recursos Naturais (PPGRN). Campina Grande, PB, Brasil. \\ ORCID: http://orcid.org/0000-0001-6139-8241. E-mail: ivanklin.filho@gmail.com \\ 3 Universidade Federal do Ceará, Instituto de Ciências do Mar (LABOMAR). Fortaleza, CE, Brasil. \\ ORCID: http://orcid.org/0000-0003-1544-7297. E-mail: luis.ernesto@ufc.br
}

\begin{abstract}
Two species of bopyrid isopods from the subfamily Athelginae are recorded from new localities in northeastern Brazil. Parathelges foliatus Markham, 1972 was recorded for the first time from Brazil, in the state of Ceará, parasitising the hermit crab Clibanarius symmetricus (Randall, 1840). Pseudostegias atlantica Lemos de Castro, 1965 is recorded from the state of Ceará, parasitising Clibanarius antillensis Stimpson, 1859. Illustrations, species diagnosis and an updated distribution map are given for each species.
\end{abstract}

Key-Words. Bopyrids; Parathelges; Pseudostegias; Taxonomy; Western Atlantic.

\section{INTRODUCTION}

Bopyridae Rafinesque, 1815 is one of the most diverse families within Isopoda, comprising more than 600 species distributed in nine subfamilies: Argeiinae Markham, 1977a, Athelginae Codreanu \& Codreanu, 1956, Bathygyginae Markham, 2016, Bopyrinae Rafinesque, 1815, Hemiarthrinae Markham, 1972a, Keponinae Boyko et al., 2013, Orbioninae Codreanu, 1967, Phyllodurinae Markham, 1977b and Pseudioninae Codreanu, 1967 (Markham, 1972a; Boyko et al., 2008 onwards).

Athelginae comprises 44 species distributed in nine genera, all dorsopleonal parasites of paguroids (Markham, 2003; Boyko et al., 2008 onwards; Williams \& Boyko, 2016). The genus Parathelges Bonnier, 1900 has pantropical distribution and it is composed of ten species, of which only four are recorded from Western Atlantic: Parathelges occidentalis Markham, 1972 from Florida (USA), Berry Islands, Bahamas, and Margarita Island, Venezuela; P. tumidipes Markham, 1972 from Jamaica, P. piriformis Markham, 1972 from North Rock Reef, Bermuda, and P. foliatus Markham, 1972 from Port of Spain,
Trinidad (Markham, 1972b). However, none of these species have been recorded for the south Atlantic. The genus Pseudostegias Shiino, 1933 is composed of seven species, and only P. atlantica Lemos de Castro, 1965 has been recorded from Brazil.

The present paper aims to provide the first record of $P$. foliatus for the south portion of the Atlantic Ocean, and an additional record of $P$. atlantica from northeastern Brazil, expanding its distribution. In addition, illustrations, species diagnosis and an updated distribution map are given.

\section{MATERIAL AND METHODS}

The material examined is deposited in the Carcinological Collection of the Departamento de Zoologia, Universidade Federal do Rio Grande do Sul, Porto Alegre, Rio Grande do Sul, Brazil (UFRGS) and the Carcinological Collection of the Laboratório de Invertebrados Marinhos do Ceará, Departamento de Biologia, Universidade Federal do Ceará, Fortaleza, Ceará, Brazil (UFC). Specimens are stored in $75 \%$ ethanol and identifications are based on morphological characters 
according Lemos de Castro (1965) and Markham (1972b). The appendages were dissected and were mounted as micropreparations. The illustrations were obtained with the aid of camera lucida mounted on a stereomicroscope and compound microscope. The references are provided for the taxonomic authorities of all parasitic taxa, but not for those of hosts.

\section{Abbreviation \\ $\mathrm{TL}=$ total length \\ $\mathrm{SL}=$ shield length}

\section{RESULTS}

\section{Taxonomy}

Order Isopoda Latreille, 1817

Suborder Cymothoida Wägele, 1989

Family Bopyridae Rafinesque, 1815

Subfamily Athelginae Codreanu \& Codreanu, 1956 Genus Parathelges Bonnier, 1900

Type species: Athelges aniculi Whitelegge, 1897 (by original designation). Gender: masculine.

\section{Parathelges foliatus Markham, 1972b}

(Figs. 1, 4)

Parathelges foliatus Markham, 1972b: 73, figs. 14, 15. Markham, 2003: 74.

Material examined: BRAZIL: Ceará: one female, Camocim, Estuário do Rio Coreaú (0253'42"S, $40^{\circ} 51^{\prime} 31^{\prime \prime W}$ ), coll. F.B. Ribeiro, 13/X/2008, identified by D. Roccatagliata and F.B. Ribeiro, 13/X/2008, (UFRGS 5970), infesting pleon of an ovigerous female of Clibanarius symmetricus (Randall, 1840) (5 mm CL; UFC 230).

Diagnosis: Female: cephalon spade-shaped in outline, eyes absent, barbula with three sharp projections on each side, pereopods all alike and with prominent coxal segments, pleon with distinct segments, exopodites of pleopods long and rounded at ends, pleotelson not set off. Males are unknown.

Remarks: Parathelges foliatus was described based on a female (TL $8.33 \mathrm{~mm}$ ) from Trinidad, being reported only from the type-locality (Markham, 1972b). The specimen examined here is morphologically similar to the material described by Markham (1972b), showing the pereon with all segments well distinguished dorsally, marsupium closed ventrally, pleopodal exopodites on peduncles and with distal margins rounded (Fig. 1A, B). Additional morphological characters not mentioned in previous descriptions include: antennule with three articles and antenna with four articles (Fig. 1C, D), and pereopod 7 with dactylus embedded in the propodus (Fig. 1I). This is the first record of this species from Brazilian waters and second for the western Atlantic Ocean. In addition, this is the third genus of Athelginae recorded from Brazil; the genera Anathelges Bonnier, 1900 from the state of Santa Catarina and Pseudostegias are known from the states of Ceará and Alagoas, respectively (Brasil Lima, 1998).

Representatives of the genus Parathelges infest diogenid hermit crabs of the genera Allodardanus Haig \& Provenzano, 1965, Calcinus Dana, 1851, Clibanarius Dana, 1852 and Dardanus Paul'son, 1875 (Markham, 2003). Parathelges foliatus was described infesting the same host of our specimen, the hermit crab Clibanarus vittatus (Bosc, 1802). However, Negri et al. (2014) established that populations of $C$. vittatus should be restricted to the southeastern coast of the United States and Gulf of Mexico. Specimens from the Caribbean to southern Brazil should be classified as Clibanarius symmetricus (Randall, 1840), which is therefore the identity of the host of P. foliatus. According to Markham (1972b), species of Parathelges are usually found associated with shallow-water hosts, which agrees with our specimen collected attached to a hermit crab in the intertidal zone of an estuarine area.

Distribution: Western Atlantic: Trinidad and Brazil (state of Ceará) (Fig. 4).

\section{Genus Pseudostegias Shiino, 1933}

Type species: Pseudostegias setoensis Shiino, 1933 (by monotypy). Gender: masculine.

\section{Pseudostegias atlantica Lemos de Castro, 1965} (Figs. 2-3, 4)

Pseudostegias atlantica Lemos de Castro, 1965: 105, figs. 1-8. Brasil Lima, 1965: 640.

Material examined: BRAZIL: Ceará: one female and one male, Paracuru, Pedra Rachada Beach $\left(02^{\circ} 53^{\prime} 42^{\prime \prime} \mathrm{S}, 40^{\circ} 51^{\prime} 31^{\prime \prime} \mathrm{W}\right)$, coll. F.B. Ribeiro, identified by D. Roccatagliata and F.B. Ribeiro, 13/X/2008, (UFRGS 6669), infesting pleon of a male of Clibanarius antillensis Stimpson, 1859 (2.7 mm CL; UFC 506).

Diagnosis: Female: cephalon deeply inset in pereomere I and about two times as long as wide, eyes present, all pereomeres distinct, all pereopods similar in size, all pleomeres distinct and tapering posteriorly, lateral plates on pleomere $\mathrm{V}$ absent. Male: eyes present, pereon broadest at pereomere 6 , all pleomeres fused, pleopods and uropods absent.

Remarks: Pseudostegias atlantica was described based on one mature female (TL $5.5 \mathrm{~mm}$ ) and male ( $3 \mathrm{~mm}$ ) from Mucuripe beach, Fortaleza, state of Ceará, and one immature female and male from Garça Torta beach, Maceió, state of Alagoas (Lemos de Castro, 1965). The specimen 
examined here is morphologically similar to the material described by Lemos de Castro (1965), showing the cephalon with anterior margin straight, dorsal region of cephalon concave with pereomeres 1-5 directed laterally forewards, all pereopods are similar in size, pleomeres distinct, lateral plates present in pleomeres 1-5 and pleopods with leaf-like endopodites and exopodites (Fig. 2). Regarding the male specimen, it is similar to the allotype of $P$. atlantica in having the cephalon of approximately two times as wide as long with rounded anterior mar- gin and all pleomeres fused (Fig. 3); however, it differs in the absence of the dorsal carina on the pleotelson. It is very likely that the specimen analyzed by Lemos de Castro (1965) showed an artifact of preservation for this character. Additional morphological characters not mentioned in previous descriptions for the female include: antennule of three articles and antenna of six articles (Fig. 2C, D), oostegite 1 bilobed with anterior lobe subtriangular, posterior lobe with inner margin concave, oostegites 2-3 subrectangular and oostegites 4-5 subtri-
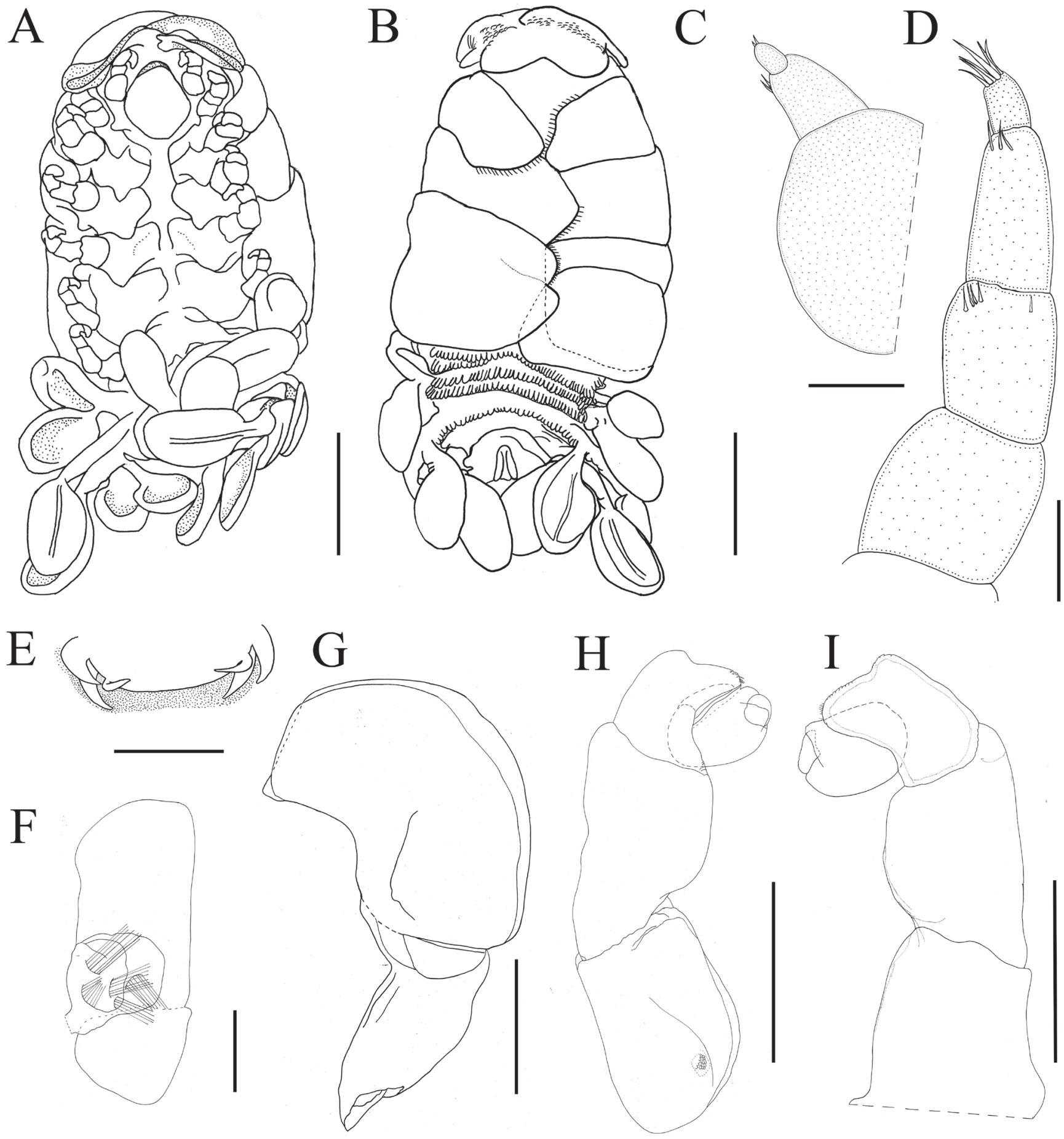

Figure 1. Parathelges foliatus Markham, 1972 (UFRGS 5970): (A) habitus dorsal view; (B) habitus ventral view; (C) antennula; (D) antenna; (E) barbula; (F) maxilliped; (G) oostegite 1; $(H)$ pereopod 1; (I) pereopod 7. Scale bars: $A$ and $B=5 \mathrm{~mm} ; C=0.1 \mathrm{~mm} ; D$ and $G=0.5 \mathrm{~mm} ; E=0.1 \mathrm{~mm} ; \mathrm{F}, \mathrm{K}$ and L $=1.00 \mathrm{~mm} ; \mathrm{H}=0.3 \mathrm{~mm}$; $\mathrm{I}=1.5 \mathrm{~mm}$. 


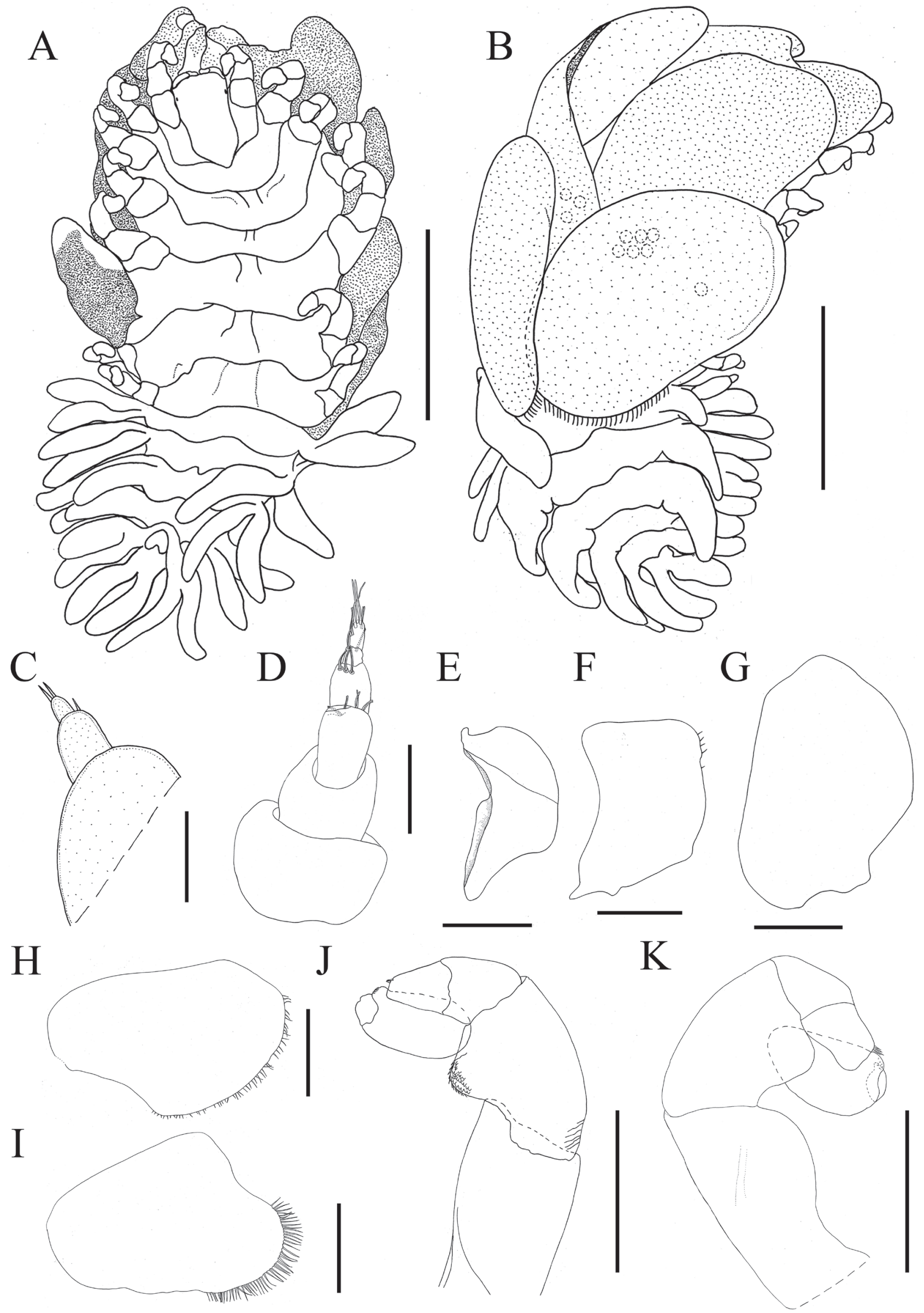

Figure 2. Pseudostegias atlantica Lemos de Castro, 1965, female (UFRGS 6669): (A) habitus dorsal view; (B) habitus ventral view; (C) antennule; (D) antenna; (E) 00stegite 1; (G) oostegite 2; (G) oostegite 3; $(\mathrm{H})$ oostegite 4; (I) oostegite 5; (J) pereopod 1; (K) pereopod 7. Scale bars: $A$ and B $=2 \mathrm{~mm} ;($ and D $=0.125 \mathrm{~mm} ; \mathrm{E}-\mathrm{I}=1 \mathrm{~mm}$. 
A

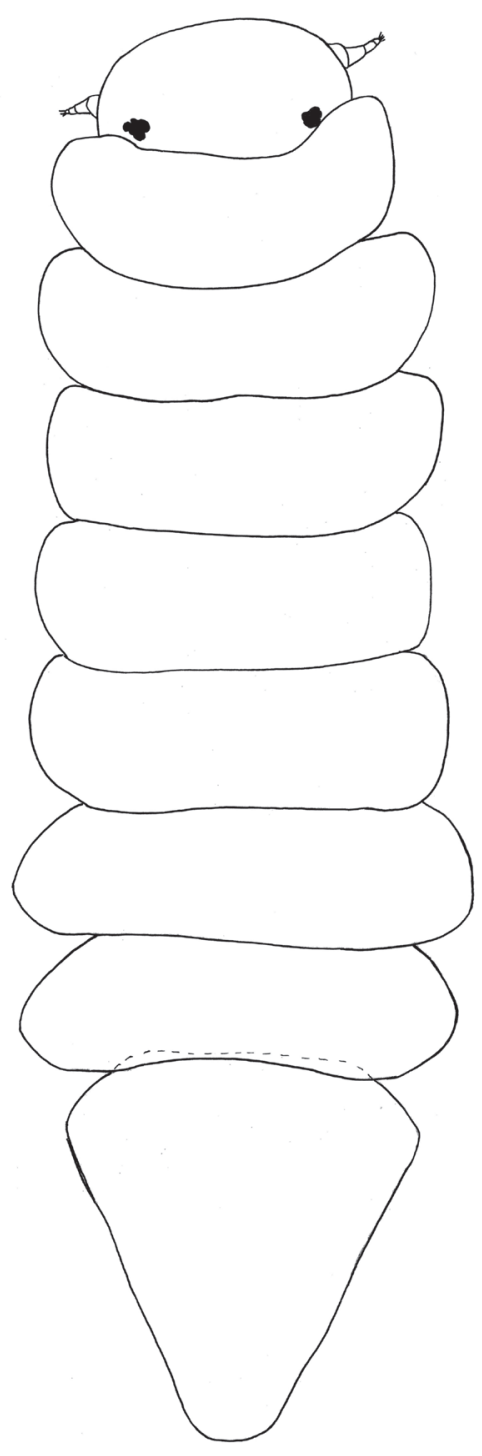

B

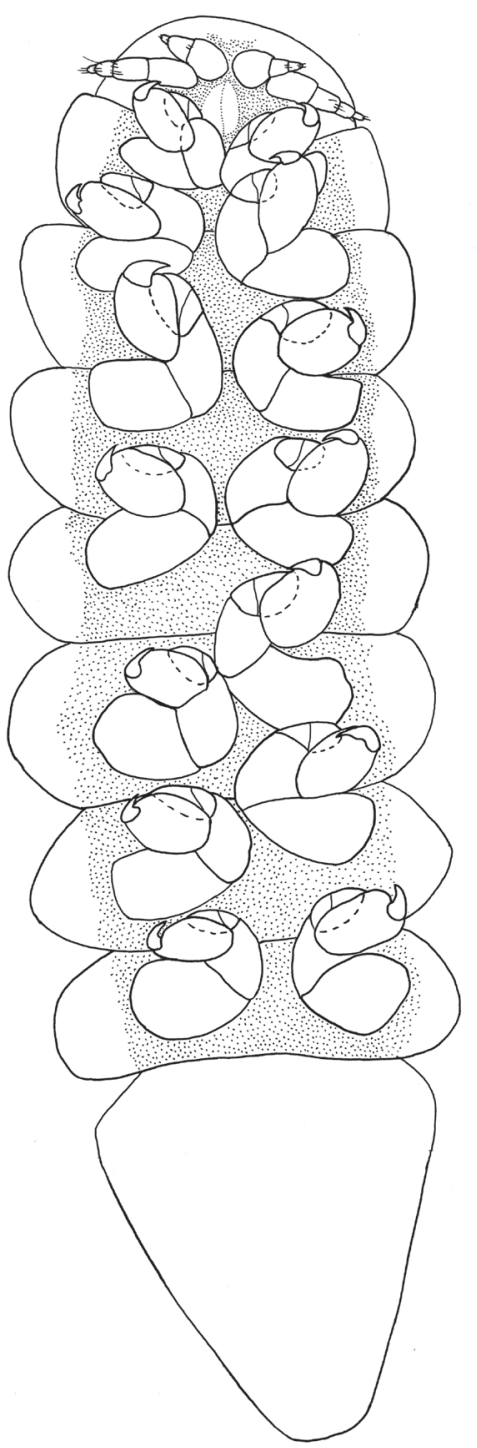

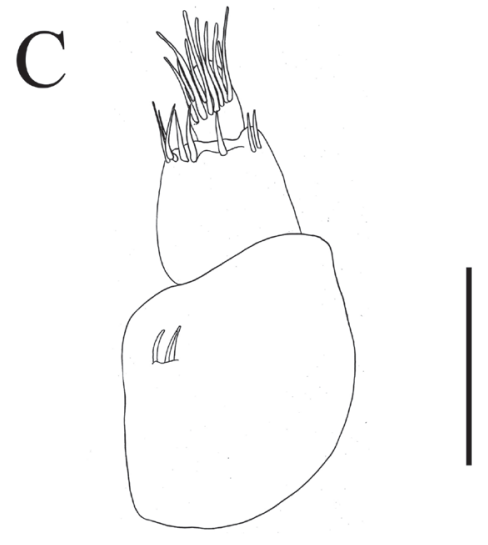

D

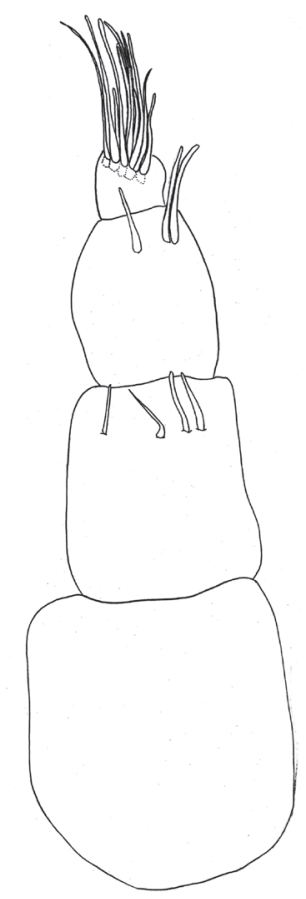

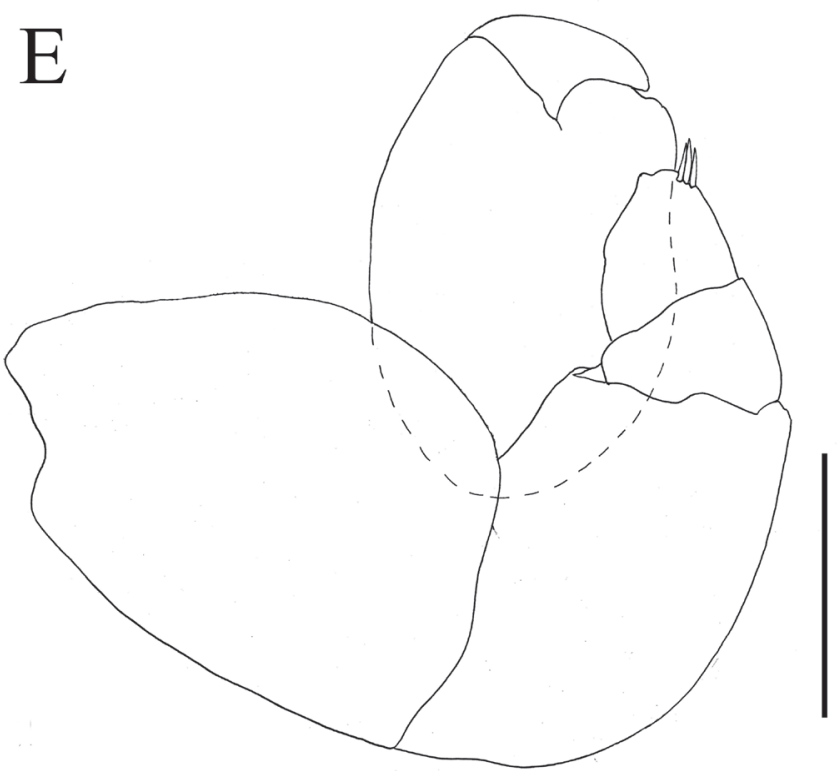

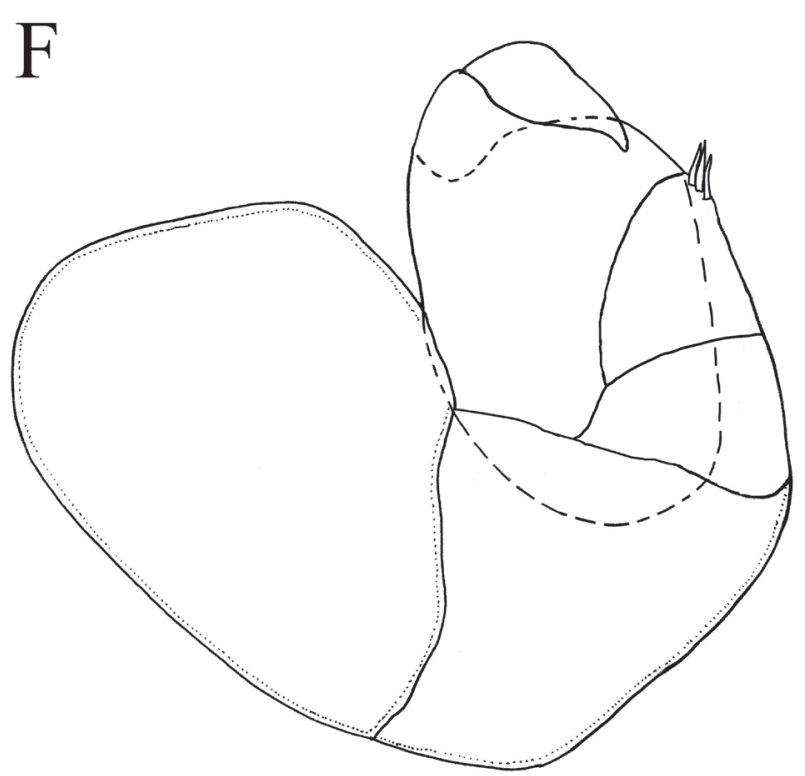

Figure 3. Pseudostegias atlantica Lemos de Castro, 1965, male (UFRGS 6669): (A) habitus dorsal view; (B) habitus ventral view; (C) antennula; (D) antenna; (E) left pereopod 1; (F) left pereopod 7. Scale bars: $A$ and $B=0.5 \mathrm{~mm} ; C$ and $D=0.025 \mathrm{~mm} ; E$ and $F=0.05 \mathrm{~mm}$. 


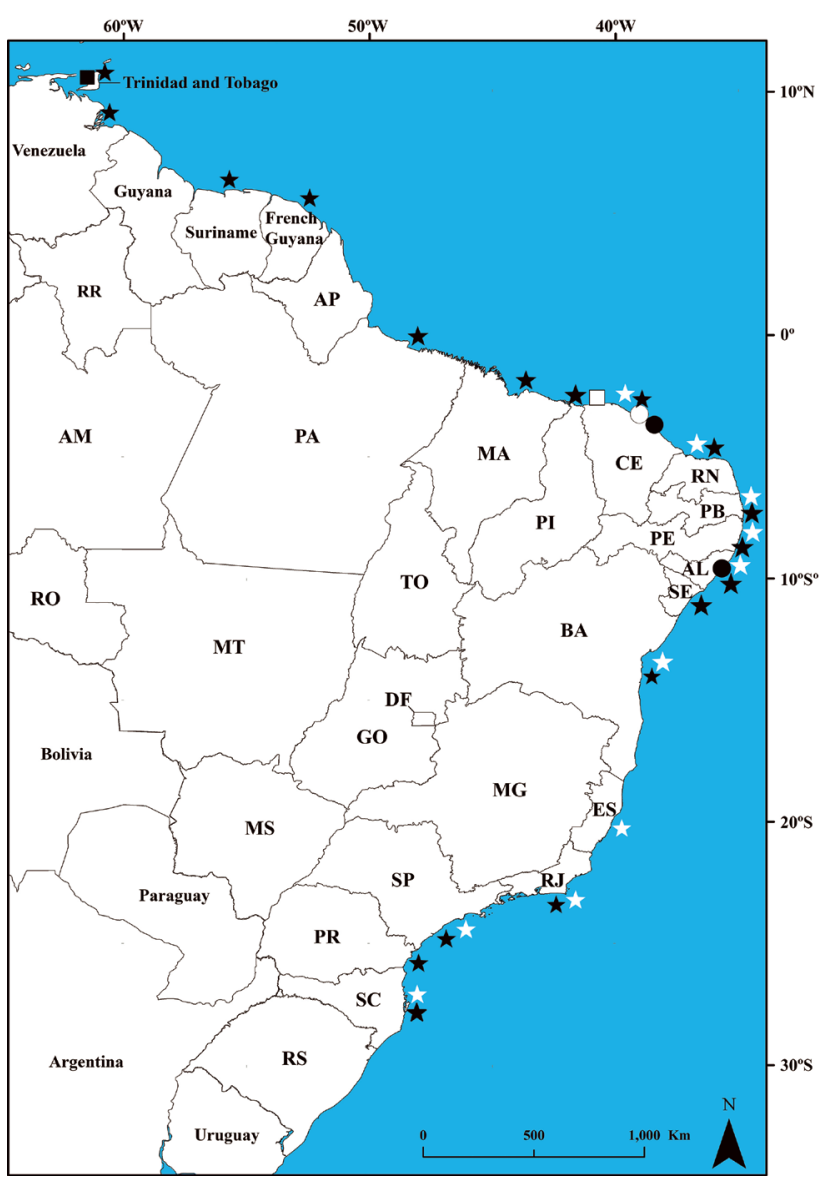

Figure 4. Distribution map of parasites (Parathelges foliatus and Pseudostegias atlantica) (circles and squares) and associated hosts (hermit (rabs) (stars). Black circles and squares represent previous records and white circles and squares new records for parasites. White and black stars represent the distribution of Clibanarius antillensis and C. symmetricus respectively from Venezuela to Brazil according to Coelho et al. (2007), Negri et al. (2014), Nucci \& Melo (2015) and Lemaitre \& Tavares (2015).

angular (Fig. 2E-I); and for the male, antennule of three articles and antenna of four articles (Fig. 3C, D), all pereopods subequal in size and shape (Fig. 3B), and pereopods 1 and 7 bears three setae in the distal margin of carpus (Fig. 3E, F). The barbula and maxilliped were not illustrated due to the condition of the material.

Pseudostegias is a genus of by pleonal parasites of diogenid hermit crabs of the genera Calcinus Dana, 1851, Clibanarius Dana, 1852, Diogenes Dana, 1851, Paguristes Dana, 1851; pagurid hermit crabs of the genus Strigopagurus Forest, 1995; and lithodid anomurans of the genus Hapalogaster Brandt, 1850 (Markham, 2003). All specimens used in the original description of $P$. atlantica were found associated to a host identified as Clibanarius sp. (Lemos de Castro, 1965). The specimens in our study were found infesting the hermit crab Clibanarius antillensis Stimpson, 1859 from Pedra Rachada Beach, Paracuru, state of Ceará. This new record is about $100 \mathrm{~km}$ from the previous record in this state.

Distribution: Western Atlantic: Brazil (states of Ceará and Alagoas) (Fig. 4).

\section{CONCLUSION}

The broad distribution of the host species on the Brazilian coast suggest the likelihood that their bopyrid parasites can also have a much wider distribution than currently reported in Brazil (Fig. 4). In addition, considering the current diversity of the Athelginae, three known species, and the Brazillian coastal extension, probably the diversity of the subfamily is still underestimated. Future surveys, in order to obtain more material, will allow the accurate identification of already known species and possible discovery of new taxonomic entities.

\section{ACKNOWLEDGMENTS}

We are greatful to Professor Daniel Roccatagliata from Universidad de Buenos Aires (UBA) for the helping to identify the specimens and Conselho Nacional de Desenvolvimento Científico e Tecnológico for the fellowship provided to FBR (PDJ154614/2018-1). This study was financed in part by CAPES with the Coordenação de Aperfeiçoamento de Pessoal de Nível Superior, Finance Code 001, and a PNPD scholarship to ISC-F (CAPES/ PNPD/UFCG/CTRN/PPGRN/201713705-5).

\section{REFERENCES}

Bonnier, J. 1900. Contribution à l'étude des épicarides. Les Bopyridae. Travaux de l'Institut Zoologique de Lille et du Laboratoire de Zoologie Maritime de Wimereux, 8: 1-478.

Boyko, C.B.; Bruce, N.L.; Hadfield, K.A.; Merrin, K.L.; Ota, Y.; Poore, G.C.B.; Taiti, S.; Schotte, M. \& Wilson, G.D.F. (Eds). 2008 onwards. World Marine, Freshwater and Terrestrial Isopod Crustaceans database. Bopyridae Rafinesque, 1815. Accessed through: World Register of Marine Species at: $\quad$ http://www.marinespecies.org/aphia.php?p=taxdetails\&id=1195 on 2019-04-28.

Boyko, C.B.; Moss, J.; Williams, J.D. \& Shields, J.D. 2013. A molecular phylogeny of Bopyroidea and Cryptoniscoidea (Crustacea: Isopoda). Systematics and Biodiversity, 11(4): 495-506. DOI

Brasil Lima, I.M. 1998. Malacostraca - Peracarida. Isopoda - Epicaridea. In: Young, P. (ed.). Catalogue of Crustacea of Brazil. Rio de Janiero: Museu Nacional, pp. 635-644.

Codreanu, R. 1967. Clasificarea evolutiva a bopirienilor, isopode parazite ale crustaceelor decapode si importanta lor biologica generala. Studii si Cercetari de Biologie Seria Zoologie, 19(3): 203-211.

Codreanu, M. \& Codreanu, R. 1956. Un epicarid abdominal nou pentru Marea Neagra, Anisarthrus pelseneeri Giard 1907, parazit pe creveta Athanas nitescens Leach. Revisuirea si raspindirea genului Anisarthrus. Buletin Stiintific. Academia Republicii Populare Romîne. Sectia de Biologie si Stiinte Agricole, 8: 568-584.

Coelho, P.A.; Almeida, A.0.; Bezerra, L.E.A. \& Souza-Filho, J.F. 2007. An updated checklist of decapod crustaceans (infraorders Astacidea, Thalassinidea, Polychelida, Palinura, and Anomura) from the northern and northeastern Brazilian coast. Zootaxa, 1519: 1-16.

Latreille, P.A. 1817. Nouveau dictionnaire d'histoire naturelle appliquéaux arts à l'agriculture, à l'economie rural et domestique, à la medicine, etc. . . nouvelle edition presqu'entierement refundue et considérablement augmentée, avec des figures tirées des trios règnes de la nature. Paris, 25: 610. 
Lemaitre, R. \& Tavares, M. 2015. New taxonomic and distributional information on hermit crabs (Crustacea: Anomura: Paguroidea) from the Gulf of Mexico, Caribbean Sea, and Atlantic coast of South America. Zootaxa, 3994(4): 451-506.

Lemos de Castro, A. 1965. Crustáceos Isópodos Epicarídeos do Brasil. I: Descrição de uma espécie nova do gênero "Pseudostegias" Shiino (Isopoda, Bopyridae). Revista Brasileira de Biologia, 25: 105-108.

Markham, J.C. 1972a. Two new genera of western Atlantic abdominally parasitizing Bopyridae (Isopoda, Epicaridea), with a proposed new name for their subfamily. Crustaceana, Supplement 3: 39-56.

Markham, J.C. 1972b. Four new species of Parathelges Bonnier, 1900 (Isopoda, Bopyridae), the first record of the genus from the western Atlantic. Crustaceana, Supplement 3: 57-78. http://www.jstor.org/ stable/25027409.

Markham, J.C. 1977a. Description of new western Atlantic species of Argeia Dana with a proposed new subfamily for this and related genera (Crustacea Isopoda, Bopyridae). Zoologische Mededelingen, 52(9): 107-123.

Markham, J.C. 1977b. The status and systematic position of the species of the bopyrid isopod genus Phyllodurus Stimpson, 1857. Proceedings of the Biological Society of Washington, 90: 813-818.

Markham, J.C. 2003. A worldwide list of hermit crabs and their relatives (Anomura: Paguroidea) reported as hosts of Isopoda Bopyridae. Memoirs of Museum Victoria, 60(1): 71-77.

Markham, J.C. 2016. Redescription of Bathygyge grandis Hansen, 1897 (Crustacea, Isopoda, Bopyridae) from Southern California with erection of a new subfamily, Bathygyginae, for it. Bulletin of the Southern California Academy of Sciences, 115: 72-80.

Negri, M.; Lemaitre, R. \& Mantelatto, F.L. 2014. Molecular and morphological resurrection of Clibanarius symmetricus (Randall, 1840), a cryptic species hiding under the name for the "thinstripe" hermit crab C. vittatus (Bosc, 1802) (Decapoda: Anomura: Diogenidae). Journal of Crustacean Biology, 34(6): 848-861.

Nucci, P.R. \& Melo, G.A.S. 2015. Hermit crabs from Brazil: Family Diogenidae (Crustacea: Decapoda: Paguroidea), except Paguristes. Zootaxa, 3947(3): 327-346.

Rafinesque, C.S. 1815. Analyse de la nature ou Tableau de l'univers et des corps organisés. [Book]. 1-224, (self-published) Palermo.

Shiino, S.M. 1933. Bopyrids from Tanabe Bay. Memoirs of the College of Science, Kyoto Imperial University (B), 8(3, Article 8): 249-300.

Wägele, J.W. 1989. Evolution und phylogenetisches System der Isopoda. Zoologica, 140: 1-262.

Whitelegge, T. 1897. The atoll of Funafuti, Ellice Group: its zoology, botany, ethnology and general structure. VI. The Crustacea. Memoirs of the Australian Museum, 3: 127-151.

Williams, J.D. \& Boyko, C.B. 2016. Abdominal bopyrid parasites (Crustacea: Isopoda: Bopyridae: Athelginae) of diogenid hermit crabs from the western Pacific, with descriptions of a new genus and four new species. Raffles Bulletin of Zoology, 64: 33-69. 